\section{En annerledes lærebok for leger i spesialisering i psykiatri}

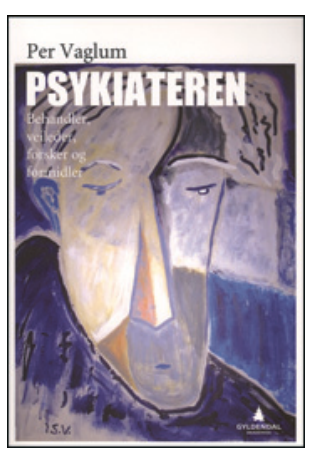

Per Vaglum

Psykiateren

Behandler, veileder, forsker og formidler.

261 s. Oslo: Gyldendal Akademisk, 2014.

Pris NOK 375

ISBN 978-82-05-46232-8

I forordet skriver forfatteren at boken særlig henvender seg til yngre kolleger i psykiatri og barne- og ungdomspsykiatri, men at den også kan være av interesse for medisinske studenter og andre faggrupper i psykisk helsevern.

Boken er innholdsrik, men ikke direkte lettlest. Den er delt inn i fire deler: Psykiaterens rolle og identitet, psykiateren som person, psykiateren som behandler og psykiateren som veileder, forsker og formidler.

Forfatteren har usedvanlig lang og bred erfaring som dobbeltspesialist i barne- og ungdomspsykiatri og voksenpsykiatri, klinisk veileder, psykoterapiveileder, lærer, forsker, lærebokforfatter og forfatter, og boken vitner om en forfatter med stort engasjement for utdanning, utdanningskandidater og sitt fag. Forfatteren bruker seg selv og sin egen historie for å illustrere enkelte temaer, noe som passer godt i en slik bok.

På mange måter er boken bygd opp om psykiaterens sju roller etter mønster fra «the profile of the psychiatrist» (The European Union of Medical Specialists, UEMS), selv om dette ikke gjøres eksplisitt. Dette bidrar til å sette psykiaterrollens mange oppgaver inn i en sammenheng og en struktur som kravene i spesialistutdanningen i psykiatri er bygd opp om. Lederrollen får liten omtale.

Kjerneholdninger defineres og diskuteres på en grundig, men samtidig jordnær måte. Sjelden gis holdninger en så bred drøfting; dette likte jeg.

Psykiateren som person i møte med pasienter og seg selv gis bred omtale. Viktigheten av å bevisstgjøre egne personlighetstrekk, følelsesmessige reaksjonsmønstre og mestringsmekanismer fremheves.

Forfatterens faglige ståsted er tydelig forankret i psykodynamisk tradisjon. De psykodynamiske begrepene danner i stor grad grunnlag for målbeskrivelsen i spesialistutdanningens grunnleggende psykoterapiutdanning. Selv om dette er et tydelig faglig utgangspunkt i boken, oppfatter jeg ikke at det gjør den ideologisk innsnevret. Temaene er i stor grad allmenngyldige.

I det siste kapitlet stiller forfatteren spørsmålet om psykiatere trengs i fremtiden. Han har underbygd sitt svar om psykiaterens brede kompetanse gjennom hele boken, men påpeker nødvendigheten av rammebetingelsene for god praksisutøvelse og uttrykker bekymring for dagens utvikling på mange områder. Dette er viktige tanker i dagens helsevesen, både med hensyn til psykiaterens rolle i det tverrfaglige teamet og at produksjon av tjenester lett kan få mer oppmerksomhet enn tjenestenes kvalitet.

Boken anbefales som en «annerledes lærebok» for utdanningskandidater i psykiatri. Den presenterer viktige refleksjoner knyttet til daglig praksisutøvelse.

\section{Salg av organer: Nødt til å kjøpe - nødt til å selge}

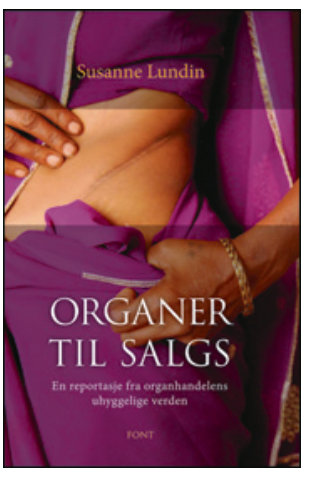

Susanne Lundin

Organer til salgs

En reportasje fra organhandelens uhyggelige verden. 224 s. Oslo: Font Forlag, 2014.

Pris NOK 299

ISBN 978-82-8169-305-0

I denne lettleste og engasjerende boken følger vi forskeren Susanne Lundin på en spennende reise fra organkjøpere i Sverige til selgere i Moldova, formidlere i Israel, leger på Filippinene og til et syndikat i Sør-Afrika. Boken svarer på to viktige spørsmål: Hvor kommer nyrene fra? Hvordan kommer de til kjøperen? I debatter om kjøp og salg av organer tas ofte svarene på disse spørsmålene for gitt, uten at antakelsene er særlig godt begrunnet.

Svaret på det første spørsmålet er at organene kommer fra fattige land i Øst-Europa, Midtøsten, Sør-Amerika, India og ulike land i Afrika. Mottakerne er innbyggere i rike land som Israel, USA, Tyskland, Storbritannia, Saudi-Arabia, og Skandinavia. Måten dette skjer på, er kompleks. Susanne Lundin gir oss innblikk i et intrikat system av kjøpere, selgere og mellommenn som alle fanges av et system, og som gjør det vanskelig å skille mellom offer og utbytter. Det er for enkelt å si at det er rike kjøpere som utnytter fattige selgere.

Forfatteren viser at det er en rekke forhold som fremmer kjøp og salg av organer. For det første finnes det alvorlig syke mennesker som kjemper for å overleve. Dessuten er det fattige mennesker som ønsker å forbedre sin livssituasjon. I tillegg finnes det organformidlere og leger, som undersøker selgere og som gjennomfører operasjonene. Som forsker på medisin og kultur gir Susanne Lundin oss dessuten innblikk i sosiale forutsetninger for organhandel: Folks holdninger og verdivurderinger, synet på kropp, sykdom, på liv og død, samt markedstenkning og menneskers verdi. Alt dette bruker hun for å forstå hva som driver organhandel, og hva vi må tenke på når vi skal forhindre og begrense de negative konsekvensene av slik handel. Lundin viser på en fin måte hvordan vi må ha de empiriske premissene på plass om vi skal håndtere et voksende og vanskelig problem, både internasjonalt og nasjonalt.

Boken belyser også legens rolle. Den viser hvordan transplantasjonskirurgene mener at de bare gjør jobben sin, og at legene selv føler seg som ofre i et spill. Men mens forfatteren ellers er svært forsiktig med å fordele ansvar og skyld, er hun mye mindre tilbakeholden når det gjelder legene og syndikatlederne.

Dette er en leseverdig bok for alle som vil orientere seg om internasjonal organhandel. Men mest av alt er boken farlig: Den problematiserer på en stillferdig måte påstandene til de som kategorisk fordømmer organhandel, og undergraver effektivt argumentene til de som ønsker (regulert) organhandel velkommen.

\section{Bjørn Hofmann}

Professor, Hanover, New Hampshire, USA 